\title{
Attractiveness of a lateral shelter in a channel as a refuge for juvenile brown trout during hydropeaking
}

\author{
J.-M. Ribi · J.-L. Boillat $\cdot$ A. Peter • \\ A. J. Schleiss
}

Received: 3 September 2013/Accepted: 5 April 2014/Published online: 22 April 2014

(C) Springer Basel 2014

\begin{abstract}
Peak power production in hydroelectric storage power plants results in frequent and intense flow variations in the rivers downstream of the plants. Fish populations can be negatively impacted when subjected to these so-called hydropeaking phenomena. In researching mitigation solutions, shelters in the riverbanks of channelized rivers have been identified as a means of protecting fish from excessive flow velocities. These shelters were studied systematically using juvenile brown trout (Salmo trutta fario) in an experimental configuration in which a straight channel was equipped with a lateral embayment. The purpose of the experiments was to generate hydrodynamic hydropeaking conditions in the channel that are undesirable for juvenile trout, thereby causing them to enter the shelter. The flow velocity distribution in the intersection plane between the main channel and the lateral shelter was found to be a significant parameter for attracting fish to the shelter. The utilization rate of trout in the shelter was used as a performance indicator. Using a basic rectangular shelter configuration without forced water exchange between the
\end{abstract}

J.-M. Ribi

Ecole d'ingénieurs et d'architectes de Fribourg, Institute of Construction and Environment, Pérolles 80, 1700 Fribourg, Switzerland

J.-M. Ribi · J.-L. Boillat · A. J. Schleiss ( $ه)$

Laboratory of Hydraulic Constructions ( $\mathrm{LCH})$, Ecole

Polytechnique Fédérale de Lausanne (EPFL), Station 18,

1015 Lausanne, Switzerland

e-mail: anton.schleiss@epfl.ch

\section{A. Peter}

Center of Ecology, Evolution and Biogeochemistry, Fish Ecology and Evolution, Eawag, Swiss Federal Institute of Aquatic Science and Technology, 6047 Kastanienbaum, Switzerland shelter and the channel, the utilization rate was only $35 \%$. This rate was more than doubled by introducing a deviation groyne to force water exchange between the channel and the shelter. The position and orientation angle of this groyne were systematically varied to maximize the utilization rate. Maximum utilization rates approaching $90 \%$ were obtained for an optimum configuration in which an island-type groyne was placed in the shelter. The results of the systematic channel tests showed the potential of the shelter to attract fish. Such a shelter could be used in channelized rivers both for morphological revitalization and to improve fish habitats. As a next step in this research, prototype shelters will be built on a natural river and monitored for 2-3 years under a hydropeaking flow regime.

Keywords Hydropeaking · Fish shelter - Groyne · Juvenile brown trout . Swimming trajectories . Ultrasonic doppler velocity profiler (UVP) · Velocity field

\section{Introduction}

Hydropower and hydropeaking in Switzerland

Hydropeaking is caused by increased electricity production at storage hydropower plants during high demand operations. Switzerland is one of the largest hydropower energy producers in the Alps in terms of its contribution to total electricity production (Schleiss 2007, 2012). Indeed, the peak energy production from storage power plants represents more than a third of the total electricity production (SFOE 2013). Thus, approximately $1,000 \mathrm{~km}$ of river lengths are affected by hydropeaking, especially the channelized Rhine and Rhône rivers, which have large 
reservoirs on tributaries located in alpine valleys (Meile et al. 2011a). Moreover, the Swiss Energy Strategy 2050 has determined that hydropower, especially peak energy production, will need to increase significantly until 2050 as a critical contribution for replacing existing nuclear power plants, reducing $\mathrm{CO}_{2}$ emissions, and compensating for the highly fluctuating supply from renewables such as photovoltaic and wind energy. Thus, future hydropower production must focus even more strongly on peak energy generation. Consequently, hydropower production will affect the flow regime of rivers more severely, which will have to be assessed and mitigated using innovative measures. Many pre-Alpine and Alpine rivers have been implicated in this problem.

Flow regime alteration by hydropeaking

Hydropeaking can strongly alter the hydrological flow regime of rivers (Meile et al. 2011a). In the absence of any precautions, the natural flow regime and associated hazards to rivers downstream of dams are generally replaced by the alternating, rhythmic and monotonous behavior of the outflow. Daily peak flows can reach up to 10-40 times the base flow, which generally corresponds to the natural flow or a residual flow. The negative impacts of such artificial flow regimes have been studied for over three decades (Baumann and Klaus 2003; Scruton et al. 2008). The ecological value of river reaches that are affected by hydropeaking can often be greatly reduced by significant changes in the river hydrological regime downstream of the restitution location of the turbinated water. The Fischnetz study (2004) showed that brown trout caught in Swiss rivers have diminished by approximately $60 \%$ since 1980 (Peter and Schager 2004). This decrease has been attributed to hydropeaking and morphological alteration by channelization. The use of hydropeaking to change the flow regime is widely recognized as a major cause of disturbance to riverine ecosystems. Nuisances are often amplified by poor river morphology because of the channelization of the effected river sections. Thus, the 2011 Swiss Federal Law on Water Protection requires that owners of storage hydropower plants implement constructive measures to mitigate the negative effects of hydropeaking.

Negative effects of hydropeaking and fish behavior

Hydropeaking is characterized by a sudden increase in flow velocities, resulting in a high peak discharge followed by a rapid decrease in discharge to a low value (Bruder et al. 2012). Sudden increases in flow velocities cause mortality in fish and invertebrates (Jungwirth et al. 2003). Less mobile macro-invertebrates and juvenile fish cannot swim sufficiently fast to find refuge in low velocity areas in large flow recirculation zones (i.e., such as around boulders, scours, and roots) when present or in substrate interstitial spaces, and thus drift with the flow (Bruno et al. 2009). The risk of drift for aquatic organisms is strongly affected by the morphological condition of the river and the density of refuges (Young et al. 2011). Water is turbinated through the powerhouses directly from reservoirs; thus, in the winter, a rapid increase in discharge occurs in combination with a sudden increase in water temperature, which influences the behavior of invertebrates (Carolli et al. 2012; Zolezzi et al. 2011). Bruder et al. (2012) reported that brown trout have difficulty moving up in the Alpine Rhine in a high speed flow and that the fish try to reach shelters to conserve energy. During the peak discharge, mobilization of the riverbed sediment can damage exposed organisms and destroy habitats in the substrate interstitial spaces (Jones et al. 2011). The degradation of natural habitats has also been observed (Valentin 1996; Ovidio et al. 2008, Gouraud et al. 2008) for a bedload transport regime that was similarly highly modified (Baumann and Klaus 2003; Eberstaller and Pinka 2001). Turbidity also increases during peak flow, producing a high seepage gradient into riverine aquifers in an inner colmation of the river bed (Fette et al. 2007). When the turbines are closed, the rapid lowering of the water surface level can strand fish on the substrate of a high water riverbed (Baumann and Klaus 2003). Rivers with a natural morphology pose a greater danger of stranding aquatic organisms than channelized rivers (Young et al. 2011; Nagrodski et al. 2012). Tuhtan et al. (2012) documented for juvenile grayling that reaches with wider and flatter cross-sections posed higher stranding risks than reaches with steeply incised channels.

Hydropeaking negatively affects fish behavior (Heggenes et al. 1996; Valentin 1996; Taylor et al. 2012; Capra et al. 2012), fish migration (Greenberg et al. 1996), spawning habitats and egg development (Courret et al. 2012), as well as juvenile development (for ages 0+) (Scruton et al. 2005, 2008). Significant differences between modified and natural flowing rivers have been observed in terms of the abundance and distribution of some sensitive invertebrate taxa, fish diversity and the energy base of the food web (Smokorowski et al. 2011). Taylor and Cooke (2012) found that changes in flow regimes of a river can influence non-migratory fish behavior and impact habitat use and energy budgets. Korman and Campana (2009) found evidence that the growth of an age- 0 rainbow trout improved on days with reduced hydropeaking, and individuals were found in immediate shoreline areas with higher water temperatures and lower velocities.

In hydropeaking rivers, the density and growth rate of juveniles was found to be reduced, and the mesohabitat was 
disturbed (Jensen and Johnsen 1999; Flodmark et al. 2006; Korman and Campana 2009). Juveniles are most endangered by displacement or stranding because of their inability to find appropriate shelter, particularly in channelized rivers. Therefore, in the present study, we identify an optimum entrance design of lateral shelters that can be implemented in the riverbanks of channelized rivers to attract juvenile trout even under severe hydropeaking conditions. The lateral shelter may also serve as a refuge for other less mobile aquatic organisms, such as invertebrates.

\section{Mitigation of hydropeaking effects}

Hydropeaking effects can be mitigated using operational, structural and morphological measures. Operational measures in storage power plants can result in severe economic consequences (Gostner et al. 2011) and are often not feasible. Structural measures include the construction of freesurface or underground compensation basins and bypass tunnels and channels (Bruder et al. 2012). Morphological measures resulting from river restoration projects can dampen the effect of flow variations. Meile et al. (2011b) investigated how introducing macro-roughness in riverbanks can dampen hydropeaking flow variations. The most efficient results can be achieved by routing the hydropeaking flow to compensation basins that serve as multipurpose reservoirs (Heller and Schleiss 2011). Person et al. (2014) provided a detailed overview on mitigation measures used to improve fish habitats in Alpine rivers that are affected by hydropower operations.

It can be counterproductive to try and improve river morphology within the framework of river restoration projects without preventing hydropeaking, which may increase the risk of stranding (Bruder et al. 2012). Under hydropeaking flow regimes, morphological measures must be designed to create habitats that remain stable during high discharge variability, i.e., without excessive flow velocities and dewatering. This challenge may be met by using specially designed lateral refuges in riverbanks of channelized rivers that serve both as fish shelters and stable habitats for small aquatic organisms. Fish shelters are not new and have been commonly used to mitigate the effects of high flow velocities (Scruton et al. 2008). Valentin (1995) and Korman and Campana (2009) highlighted the significance of using lateral bank refuges to protect fish and other aquatic organisms from rapid variations in hydraulic parameters and to provide better growth conditions. Motivated by the results of the aforementioned studies, systematic channel experiments were used in this study to investigate the attraction of juvenile brown trout to a lateral shelter as a function of its entrance geometry.

\section{Materials and methods}

Goals and research conditions

The ultimate goal of this study was to formulate criteria for the entrance design of shelters that can be implemented at riverbanks in channelized alpine rivers with a hydropeaking regime. The scientific objective was to understand and subsequently influence the behavior of fish that are subjected to excessively high velocities in the main river, such that these fish can be directed toward velocity refuges in the banks. The research methodology was based on tests on wild fish using an experimental flume. The flume was used to simulate hydrodynamic flow conditions that are hostile to fish and as they occur during hydropeaking in a channelized river downstream of the water restitution of powerhouses of storage hydropower schemes. The objective of this approach was to develop and optimize an entrance design for use as a shelter that can attract fish under hydropeaking conditions. The utilization rate of fish in the refuge was used as a performance indicator of the test configurations.

\section{Experimental study}

\section{Experimental configuration and test refuge entrance configurations}

To identify the optimum shelter configurations for attracting fish, fish were exposed to hydropeaking sequences in a channel equipped with a lateral refuge. A special flume was built in the old powerhouse of the Maigrauge dam in Fribourg (Switzerland) to obtain a permanent supply of fresh water from the reservoir (Fig. 1) and control the light intensity. The channel had an effective length of $12 \mathrm{~m}$ and a width of $1.2 \mathrm{~m}$. The refuge area had a 2-m length and a 1.2-m width and was located on the right bank.

A total of 12 configurations with different water diverting structures at the refuge entrance were tested, as shown in Fig. 2, and the geometries of these structures are detailed in Table 1. To activate the flow exchange between the channel and the refuge, a simple vertical wall was first inserted into the refuge over the entire water depth to serve as a diverting structure, as shown by configuration $\mathrm{C} 1$ in Fig. 2. The outer edge of the diverting wall protruded $0.30 \mathrm{~m}$ into the channel section. The inner edge was located $0.50 \mathrm{~m}$ from the refuge sidewall. Except for configuration C6, these values were maintained throughout all of the tested geometries by changing the angle of the wall to the flow direction (Fig. 2). Finally, with an eye toward practical applications, diverting structures with island-type geometries were also tested (see Fig. 2: C7, C8, C11). 


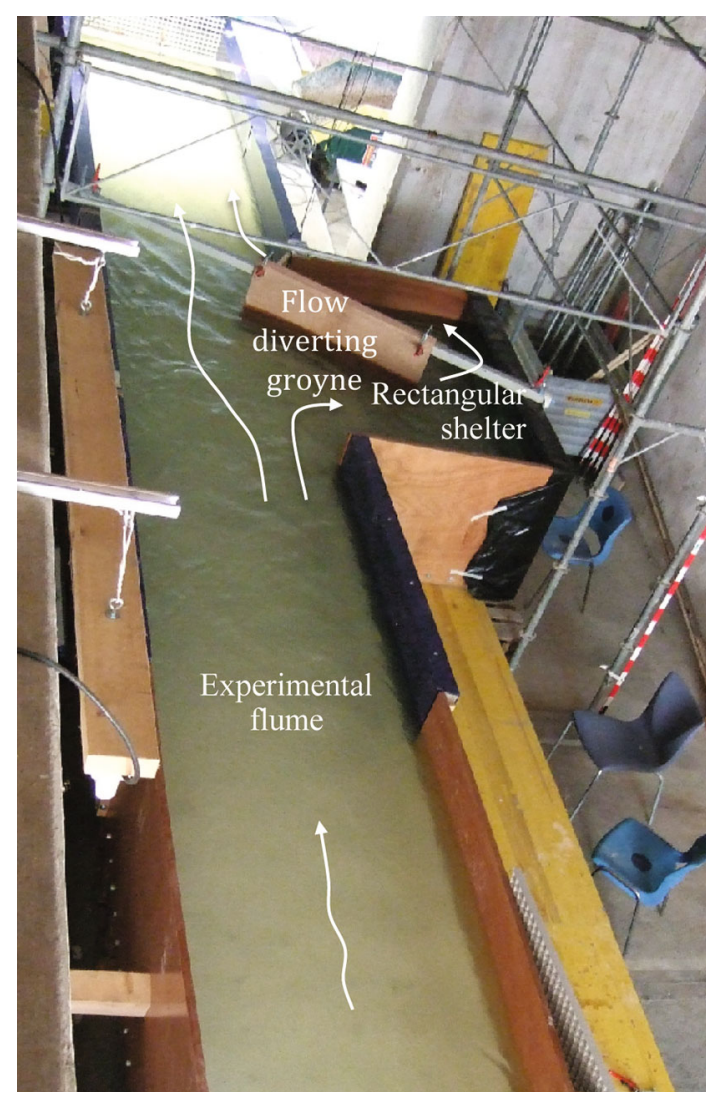

Fig. 1 Downstream topview of ecohydraulic test flume installed in the former powerhouse of the Maigrauge dam in Switzerland

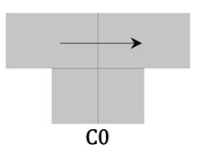

$\mathrm{CO}$
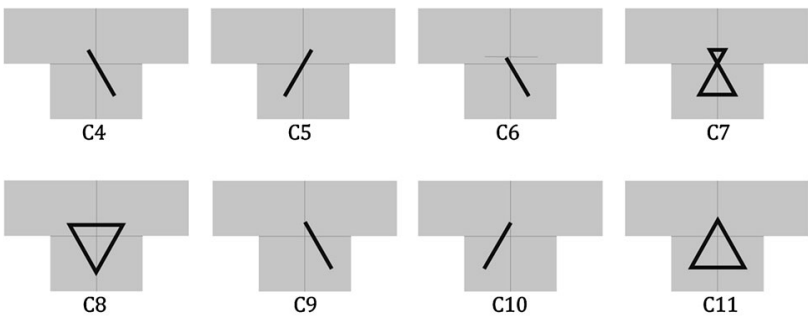

Fig. 2 Tested configurations for different shelter entrances: the bold line represents the structures tested for diverting water through the shelter

The bottom of the channel and the refuge were covered with a mixture that was two-thirds rounded medium gravel, ranging from 16 to $32 \mathrm{~mm}$ in diameter, and one-third coarser gravel, ranging from 30 to $60 \mathrm{~mm}$ in diameter. This composition corresponded to a substrate preference curve that has been reported by Valentin (1996) and Vismara et al. (2001) for juvenile brown trout. Preliminary tests on this loose substrate showed that during hydropeaking some juveniles hid in the spaces between the coarse gravel that were near the channel wall where velocities were somewhat lower. The juveniles remained almost immobile during the entire experiment even after hydropeaking subsided, showing signs of physical stress by moving their gills rapidly. To simulate fairly hostile conditions in the channel, the space between the coarse gravel was filled with mortar and a $25-\mathrm{cm}$ wide rough concrete plate (with a washed gravel surface) was placed along the channel wall. The corner between the channel bed and sidewall was filled with a $10-\mathrm{cm}$ chamfer with a $45^{\circ}$ angle. Such hostile conditions can be found in channelized rivers that are subjected to hydropeaking. In rivers below hydroelectric projects, it is very common for an armor layer of cobbles to form that can become embedded by fine sediments. This type of bed serves as a very poor velocity refuge for fish during hydropeaking, as was found using the experimental channel. Nevertheless, a loose substrate was maintained in the refuge to simulate favorable natural conditions. The coarse gravel bed was painted white throughout the channel and the refuge to enhance the visibility of fish for camera tracking.

\section{Conditions for fish experiments}

Hydropeaking conditions were produced by suddenly opening the gate for regulating the water supply. Discharge, water depths and water temperature were continuously measured during the tests.

All of the tests were performed for a hydropeaking event in the flume, starting from a base flow of $10 \mathrm{l} / \mathrm{s}$ that corresponded to a $10-\mathrm{cm}$ water depth in the flume. Then, the discharge was rapidly increased over $15 \mathrm{~min}$ to a maximum peak discharge of $220 \mathrm{l} / \mathrm{s}$, which resulted in a water depth of $24 \mathrm{~cm}$ in the flume. The evolution of the corresponding flow velocities in the flume is shown in Fig. 3 (left), which is compared directly with the velocity preference curve for juvenile brown trout (Salmo trutta fario) (i.e., ages of $0+$ and 1+) from Vismara et al. (2001). The base discharge of $10 \mathrm{l} / \mathrm{s}$ for mean flow velocities of approximately $0.1 \mathrm{~m} / \mathrm{s}$ occurred in the flume, resulting in a favorable preference index above 0.9 (see Fig. 3, right). Flow velocities rapidly increased over $15 \mathrm{~min}$ to approximately $0.8 \mathrm{~m} / \mathrm{s}$ (corresponding to an increase of $0.05 \mathrm{~m} / \mathrm{s}$ per min), resulting in very hostile conditions with a preference index below 0.2. These velocities are beyond the sustained swimming ability of juvenile brown trout.

Tests were performed with wild juvenile brown trout (Salmo trutta fario) (i.e., ages of $0+$ and $1+$ ), which were captured by electrofishing in a small stream in the Swiss Midland (at Tannenbach Buttisholz near Lucerne) prior to testing each configuration. Table 2 details the 
Table 1 Geometric parameters obtained from Fig. 2 for the tested refuge configurations: (1) length of the interface section upstream and downstream of the flow diverting structure, (2) upstream and downstream orientation angle of the flow diverting structure, and (3) depth of protrusion of the flow diverting structure into the section of the main channel

\begin{tabular}{lllllllllllll}
\hline Configuration & C0 & C1 & C2 & C3 & C4 & C5 & C6 & C7 & C8 & C9 & C10 & C11 \\
\hline Upstream length (m) & - & 0.99 & 1.38 & 0.60 & 0.99 & 0.99 & 0.99 & 0.99 & 0.60 & 1.17 & 0.81 & 0.81 \\
Downstream length (m) & - & 0.99 & 0.60 & 1.38 & 0.99 & 0.99 & 0.99 & 0.99 & 0.60 & 0.81 & 1.17 & 0.81 \\
Upstream angle $\left(^{\circ}\right)$ & - & 90 & 120 & 60 & 60 & 120 & 60 & 120 & 60 & 60 & 120 & 120 \\
Downstream angle $\left(^{\circ}\right)$ & - & 90 & 120 & 60 & 60 & 120 & 60 & 60 & 120 & 60 & 120 & 60 \\
Protrusion depth (m) & - & 0.30 & 0.30 & 0.30 & 0.30 & 0.30 & 0.15 & 0.30 & 0.30 & 0.30 & 0.30 & 0.30 \\
\hline
\end{tabular}
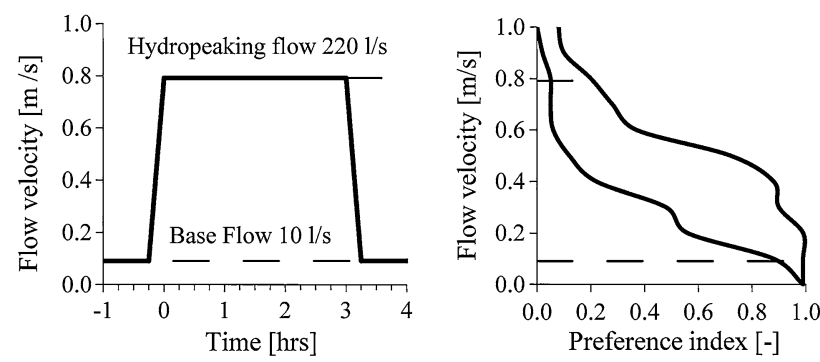

Fig. 3 Channel hydraulic parameters related to preference index for juvenile brown trout, taken from the results of different studies by Vismara et al. (2001)

Table 2 Characteristic (length) of fish captured by electrofishing in the Tannenbach river at Buttisholz village near Lucerne, Switzerland

\begin{tabular}{lrrrc}
\hline Date of electric fishing & 08.08 .08 & 14.10 .08 & 15.05 .09 & 05.10 .09 \\
\hline Number of fish caught & \multicolumn{1}{c}{21} & 22 & 33 & 20 \\
Average length (mm) & 165 & 164 & 125 & 151 \\
Maximum length (mm) & 196 & 196 & 161 & 187 \\
Minimum length (mm) & 139 & 139 & 88 & 107 \\
Standard deviation (mm) & 19 & 17 & 18 & 18 \\
\hline
\end{tabular}

characteristics of the fish that were captured by electrofishing. Brown trout is the main species found in Alpine and sub-alpine rivers and has been subject of many biological research studies on hydropeaking (Valentin 1996; Scruton et al. 2003; Flodmark et al. 2006; Gouraud et al. 2008; Murchie et al. 2008). During the experiments, groups of 10 (low density) or 20 trout (high density) were used, which resulted in a fish density of $1-2 \mathrm{fish} / \mathrm{m}^{2}$ in the channel and 10-20 fish $/ \mathrm{m}^{2}$ in the refuge. These low densities correspond to densities that have been observed in rivers with an average habitat quality for juvenile brown trout; the high densities correspond to trout streams with an excellent habitat quality for juvenile fish (Arrignon 1998; Schager et al. 2007). During hydropeaking, the density of the fish in the refuge increased and reached relatively high values over a small area. Brown trout often accumulate in high densities in a refuge. The velocities and cover provided by the refuge enable the juvenile fish to successfully maintain their position and feed on drifting macro-invertebrates during hydropeaking events. The ability to feed and grow in these refuge habitats is a significant benefit for these fish, especially if hydropeaking events occur on a frequent (e.g., daily) basis. However, macro-invertebrates were not used in the tests that were conducted in our artificial channel.

Before performing a test, a uniform flow of $10 \mathrm{l} / \mathrm{s}$ was established in the flume. The fish were then introduced in the channel entrance in a fenced repose area where they could acclimate to the water conditions. The fence was then removed, and the flow in the channel was increased from 10 to $220 \mathrm{l} / \mathrm{s}$ in approximately $15 \mathrm{~min}$ and maintained at its maximum value for $3 \mathrm{~h}$, as shown in Fig. 3. The positions of the individual fish were visually recorded every $20 \mathrm{~min}$ during the hydropeaking period, and the density of fish for the tested refuge entrance configuration was plotted (Ribi 2011).

A video camera was placed perpendicularly above the refuge to track the fish. The video recordings were analyzed frame-by-frame for particularly interesting configurations to identify preferential pathways.

Each refuge configuration was tested three times and always involved a newly captured group of fish (see Table 3): first, two different groups, A and B, of 10 fish were used, followed by a combined group, A\&B, of 20 fish. Six series of 20 fish were used for 36 experimental sequences, corresponding to a total of 12 tested entrance configurations (Fig. 2). That is, a group of 10 fish was used only twice to test the same entrance configuration of the shelter and for two to a maximum of four configurations. Typically, each fish was used for a maximum of six hydropeaking events. No change in fish behavior or learning effects was observed during the tests. Table 3 details the electro-fished groups that were used for each test and each configuration.

To prevent weight loss in the trout from bad conditions, the trout were fed before each test and three times per week with macro-invertebrates that were captured in a river near the powerhouse. The fish were allowed to recover for at least $36 \mathrm{~h}$ between each test (Table 3). Salmonid fish generally recover rapidly from stress and swimming performances (Wedemeyer and Wydoski 2008). 
Table 3 Detailed test program showing the electro-fished fish group used for each configuration, where italicized dates indicate the first time the fish group was submitted to a test

\begin{tabular}{lllll}
\hline $\begin{array}{l}\text { Date of electric } \\
\text { fishing }\end{array}$ & Configuration & Group A & Group B & Group A\&B \\
\hline 08.08 .08 & C0 & 11.09 .08 & 10.09 .08 & 12.09 .08 \\
08.08 .08 & C1 & 15.09 .08 & 16.09 .08 & 18.09 .08 \\
14.10 .08 & C2 & 20.10 .08 & 23.10 .08 & 27.10 .08 \\
14.10 .08 & C3 & 28.10 .08 & 03.11 .08 & 10.11 .08 \\
14.10 .08 & C4 & 04.11 .08 & 06.11 .08 & 07.11 .08 \\
15.05 .09 & C5 & 20.05 .09 & 22.05 .09 & 25.05 .09 \\
15.05 .09 & C6 & 28.05 .09 & 28.05 .09 & 02.06 .09 \\
15.05 .09 & C7 & 04.06 .09 & 04.06 .09 & 05.06 .09 \\
05.10 .09 & C8 & 21.10 .09 & 21.10 .09 & 19.10 .09 \\
05.10 .09 & C9 & 08.10 .09 & 08.10 .09 & 12.10 .09 \\
05.10 .09 & C10 & 16.10 .09 & 16.10 .09 & 14.10 .09 \\
05.10 .09 & C11 & 23.10 .09 & 23.10 .09 & 26.10 .09 \\
\hline
\end{tabular}

The tests were performed over 3-h sequences in the spring and autumn when the water temperatures ranged between 6 and $14{ }^{\circ} \mathrm{C}$. Figure 4 shows the temperature that was continuously and automatically measured during the tests. From the end of May to the beginning of June 2009, the automatic measurement system was out of service: thus, the mean water temperature of approximately $10{ }^{\circ} \mathrm{C}$ was measured manually. These temperatures are optimum for trout (Elliott 1994; Küttel et al. 2002; Jungwirth et al. 2003). In preliminary tests that were performed with significantly colder water, the fish exhibited a weak response to the refuge and did not enter it.

\section{Numerical flow field simulation}

The different entrance configurations of the shelters were compared using a numerical analysis of the local velocity distributions. The primary focus was on the flow exchange between the channel and the shelter and the velocity pattern at its entrance intersection. A systematic analysis was performed using a 2D simulation model based on shallow water equations. BASEMENT "BASic EnvironMENT for natural flow and hazard simulation" (Faeh et al. 2010) was used for these purposes. The model was used to solve the unsteady flow equations at an average depth using the finite volumes numerical pattern. SMS, i.e., the "Surface Water Modeling System" was used in parallel to build the simulation grid, to pre- and post-process the data and to illustrate the results. Figure 5 shows an example of such a simulation in which the base configuration $\mathrm{C} 0$ without a diverting structure was compared with the $\mathrm{C} 8$ configuration in which a triangular island was used as a diverting structure.

\section{Flow field measurements}

Horizontal flow velocities were measured at four different flow depths by an ultrasonic Doppler velocity profiler (UVP) (Met-Flow 2002) using 6 transducers at $1 \mathrm{MHz}$ that were mounted on a measurement frame. Figure 6 shows the measurement transects that were obtained using the six transducers. The vertical entrance interfaces between the refuge and the channel were investigated in detail along with two sections across the channel that were $2 \mathrm{~m}$ upstream and $0.8 \mathrm{~m}$ downstream from the shelter. Conventional measurements were also performed locally using a micro current-meter for validation. The vertical profiles were recorded six times at each measurement section at $0.025,0.05,0.075$ and $0.1 \mathrm{~m}$ (near the water surface) above the bottom. The measured velocities have been presented in detail in Ribi et al. (2010) and Ribi (2011). Particular attention was focused on measuring the velocity at a depth of $0.025 \mathrm{~m}$ above the bottom, which corresponded approximately to the swimming depth of fish approaching and entering the shelter (Ribi 2011).

\section{Results}

Velocity distributions at the interface between the channel and the refuge

Figure 7 is a plot of the measured horizontal velocity distributions at the interface between the channel and the shelter for all configurations with water diverting structures (C1-C11). Each distribution along the interface transect of $2 \mathrm{~m}$ is presented for 4 different water depths, as previously mentioned. Negative velocities indicate that the water was flowing from the channel into the refuge, and positive velocities indicate the converse. Configuration $\mathrm{C} 0$ is not presented because the zero exchange velocities were measured along the interface. In general, for all configurations, the water diverting structure forced a significant amount of water to enter the refuge upstream. However, the water left the refuge downstream of the diverting structure. In some of the tested configurations, some quantity of water left and entered at the same time upstream and downstream of the diversion structure: this behavior is most clearly visible for $\mathrm{C} 2, \mathrm{C} 9, \mathrm{C} 10$ and $\mathrm{C} 11$. This behavior indicates the presence of shear zones with zero flow velocities.

Fish utilization rates in the refuge

During each test, the number of fish in the shelter was counted every $20 \mathrm{~min}$. Figure 8 shows the test results as a 
Fig. 4 Water temperature of the Sarine River at the powerhouse of Maigrauge dam: the broken lines indicate the testing periods
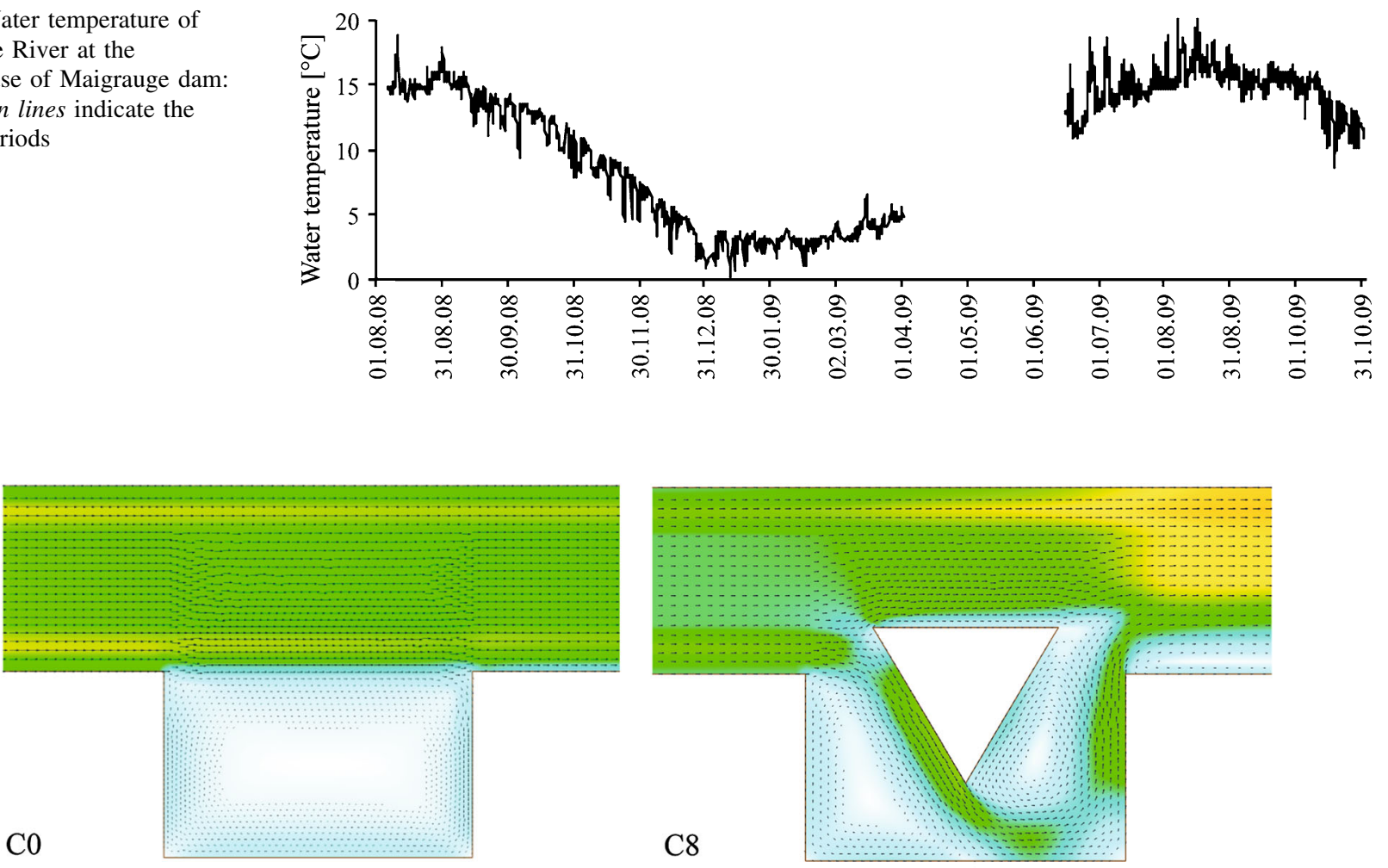

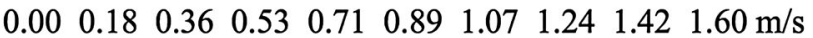

Fig. 5 Flow velocity fields simulated using BASEMENT 2D for configurations C0 and C8: the water flows from left to right, and the average flow velocity in the main channel is $0.79 \mathrm{~m} / \mathrm{s}$

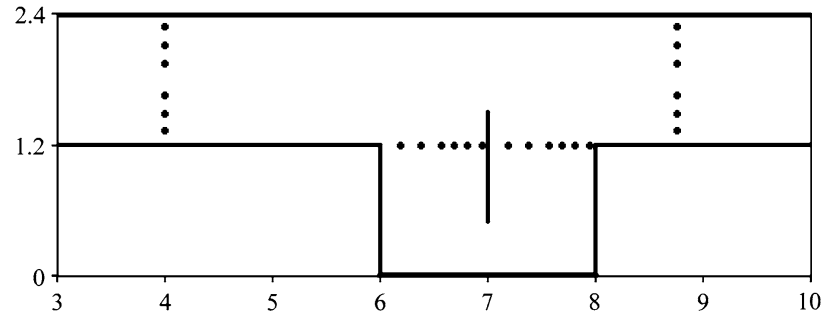

Fig. 6 Six UVP transducers distributed across a the interface section between the refuge and the channel and $\mathbf{b}$ the channel sections upstream and downstream of the shelter

percentage of the total number of fish that were used (10 or 20) for configurations $\mathrm{C} 0$ and $\mathrm{C} 8$. A fairly strong variation in fish presence rate in the refuge over $3 \mathrm{~h}$ of investigation can be observed (Fig. 8). However, averaging the three tests every $20 \mathrm{~min}$ (see the bold line in Fig. 8) revealed a clear trend in the presence rate for the different configurations. To further analyze the capacity of the different entrance configurations of the shelters to attract fish, fish utilization rates in the refuge were defined by time averaging the aforementioned averaged presence over the total duration of the experiment $(3 \mathrm{~h})$. The results are compared in Fig. 9 for all of the configurations, yielding boxplots for the time averaged utilization over $3 \mathrm{~h}$ of testing, the first and third quartiles and the extreme values. The simple lateral cavity without a diverting structure (C0) exerted a very weak attraction on the fish at an average utilization of the refuge of approximately $33 \%$ (Fig. 9: $\mathrm{C} 0$ ). This low attraction could be attributed to the nonexistent flow exchange between the main channel and the refuge. Therefore, the transit or diverted flow across the refuge was computed by integrating the simulated and measured velocities over the vertical plane separating the refuge from the main channel. Figure 10 shows the results as absolute values of the diverted discharge and as relative values in terms of a percentage of the total discharge in the main channel. For the $\mathrm{C} 0$ configuration without a diverting structure, no water was exchanged between the main channel and the refuge. As soon as a water diverting structure was inserted at the shelter entrance, the water exchange increased considerably, ranging from $11 \%$ (C6) to $22 \%(\mathrm{C} 3)$. 

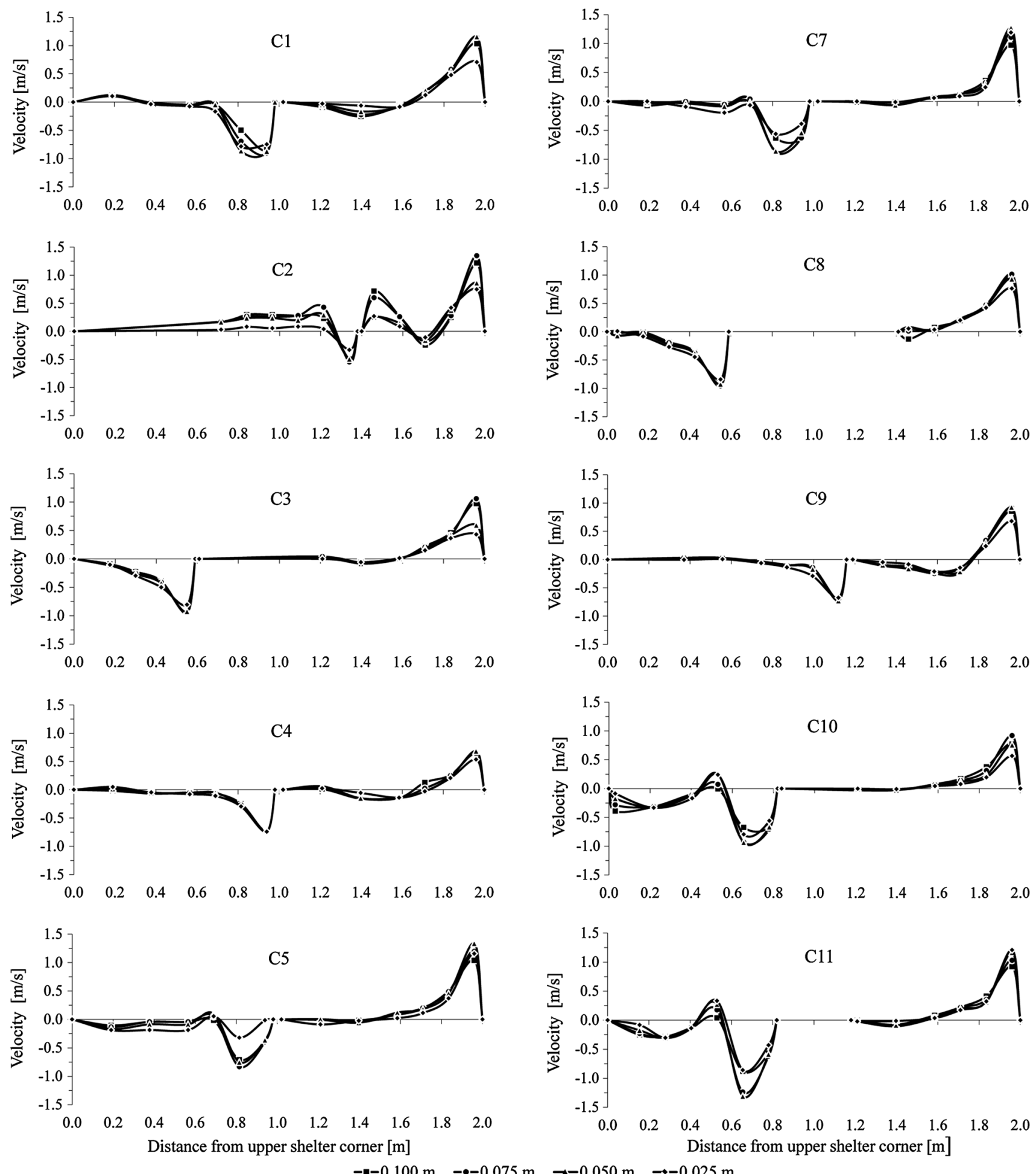

Fig. 7 Measured horizontal velocity distributions at the interface between the channel and the shelter at $0.025,0.05,0.075$ and $0.1 \mathrm{~m}$ (near the water surface) above the channel bottom

Figure 11 compares the average utilization rate to the percentage of the discharge that was diverted from the main channel into the refuge. For all configurations with a water diverting structure, the average utilization rates ranged from 57.4 (C9) to $87.4 \%$ (C8), whereas the diverted flow rate ranged between 23.5 and $48.5 \mathrm{l} / \mathrm{s}$, respectively, which was 11 to $22 \%$ of the total discharge in the experimental channel. Averaging all configurations, 

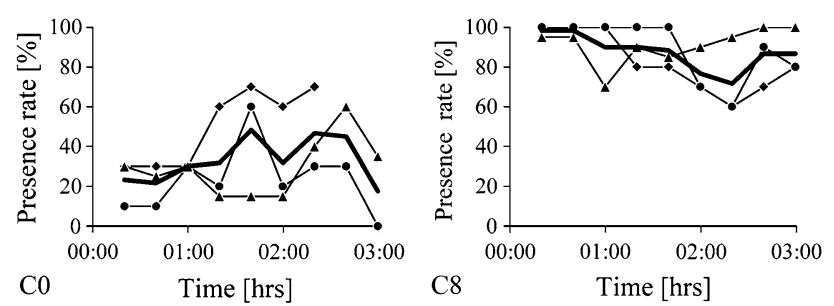

Fig. 8 Presence rate of fish in the refuge, which was counted during three tests that were conducted every $20 \mathrm{~min}$ for configurations $\mathrm{CO}$ and C8: the bold line represents the average of the three tests

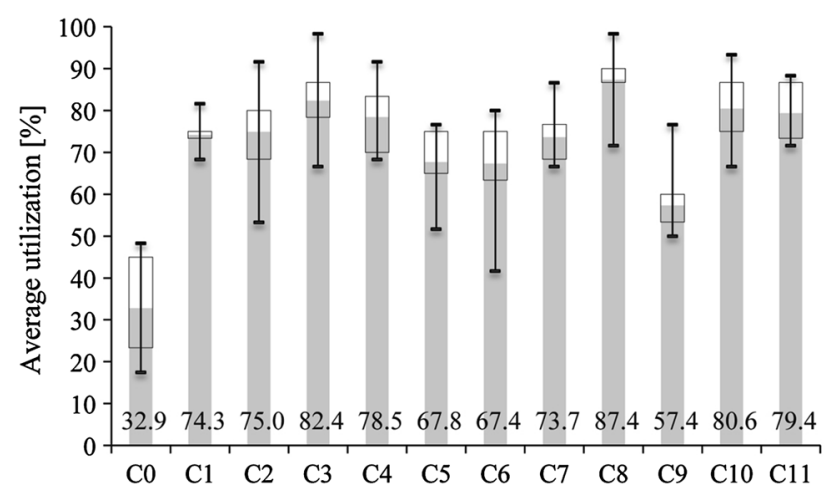

Fig. 9 Boxplots of the fish utilization rate in the shelter, which is time-averaged over three tests for each configuration to yield the average value over a 3-h test, the first and third quartiles and the maximum and minimum (all of the values are averages of the three tests for each configuration from Fig. 7)

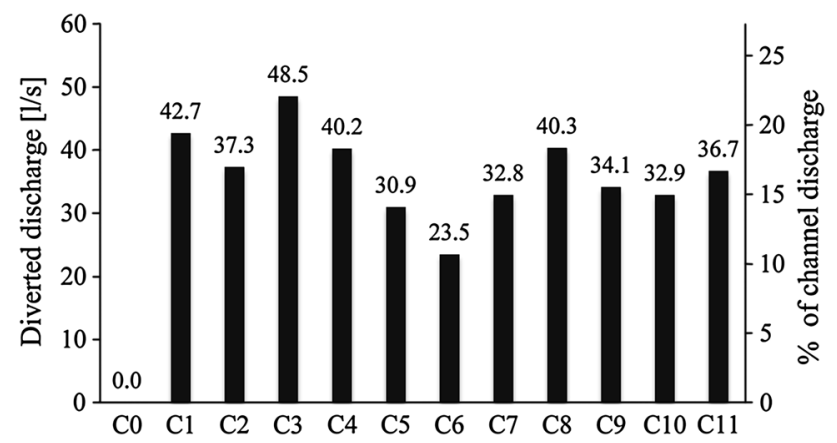

Fig. 10 Absolute and relative values of the diverted discharge from the channel through the refuge for all configurations: the relative values are given as a percentage of the total flow of $2201 / \mathrm{s}$ in the channel

but excluding $\mathrm{C} 0$, yielded a utilization rate of approximately $75 \%$ (Fig. 11). For the configurations considered, the utilization rate was above $60 \%$ as soon as approximately $15 \%$ of the water was diverted from the channel into the refuge.

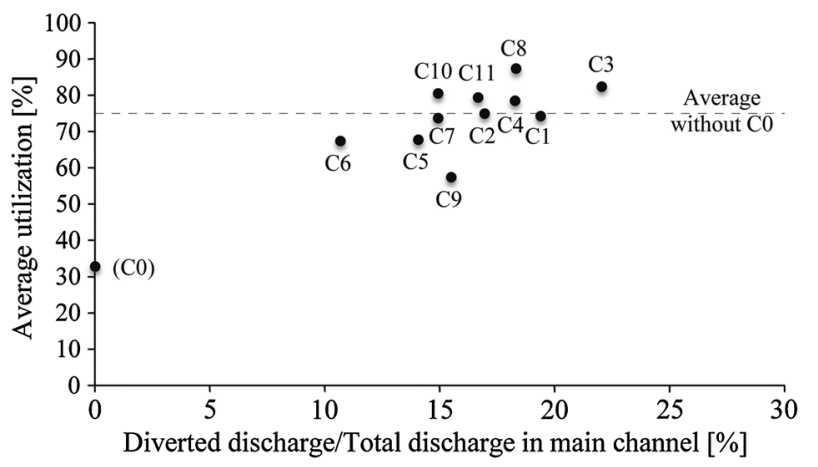

Fig. 11 Average utilization rate of the refuge by the fish as a function of the relative diverted discharge from the channel into the refuge: configuration $\mathrm{C} 0$ is shown for reference

Location of fish entries into the refuge

A video recording of the preferred travel path of fish from the channel into the refuge over a 3-h hydropeaking event was used to perform a detailed analysis of each entrance configuration. The results are summarized in Table 4 . Figure 12 also shows the number of fish that entered from upstream or downstream of the refuge for all of the configurations with water diverting structures. The number of entries per fish is also indicated in Table 4. Figure 12 shows that the fish entering the shelter during hydropeaking followed a clear preferential travel path from downstream. Figure 13 shows that the fish found a path upward of the channel along the right sidewall leading to the downstream corner of the refuge to take advantage of the relatively low velocities in that region. Individual fish rested for a few seconds as they reached the low velocity area before crossing into the higher velocity flow issuing from the refuge edge to reach the shelter behind the water diverting structure. The fish then temporarily rested behind the water diverting structure before entering deeper into the refuge, as shown in Fig. 13.

Table 4 shows the calculated statistical number of entries per fish. Less than 1 entry was generally observed for entries from upstream, whereas entries from downstream ranged from 2 to 6 . However, an analysis of the fish motion showed that there was no direct relationship between the number of entries and the utilization rate. Observations during the hydropeaking event showed that fish traveled continuously between the refuge and the channel. Some configurations elicited more fish movement than others. For example, the $\mathrm{C} 2, \mathrm{C} 5, \mathrm{C} 6, \mathrm{C} 8$ and $\mathrm{C} 9$ configurations were characterized by less than 3 entries per fish per test, i.e., the fish stayed longer in the refuge. The $\mathrm{C} 3, \mathrm{C} 4, \mathrm{C} 7, \mathrm{C} 10$ and $\mathrm{C} 11$ configurations produced more than five entries per fish per test, indicating that the fish were leaving and returning to the refuge more frequently 
Table 4 Preferential entries of fish from the channel into the refuge for all of the tested configurations: (1) fish presence rate in the refuge, (2) diverted discharge into the refuge, and (3) length of the interface section upstream and downstream of the flow-diverting structure (see also Table 1)

\begin{tabular}{|c|c|c|c|c|c|c|c|c|c|c|c|c|}
\hline Configuration & $\mathrm{C} 0$ & $\mathrm{C} 1$ & $\mathrm{C} 2$ & C3 & $\mathrm{C} 4$ & C5 & C6 & $\mathrm{C} 7$ & $\mathrm{C} 8$ & C9 & $\mathrm{C} 10$ & $\mathrm{C} 11$ \\
\hline Presence rate $(\%)$ & 32.9 & 74.3 & 75.0 & 82.4 & 78.5 & 67.8 & 67.4 & 73.7 & 87.4 & 57.4 & 80.6 & 79.4 \\
\hline Diverted discharge $1 / \mathrm{s}$ & 0.0 & 42.7 & 37.3 & 48.5 & 40.2 & 30.9 & 23.5 & 32.8 & 40.3 & 34.1 & 32.9 & 36.7 \\
\hline Upstream length (m) & - & 0.99 & 1.38 & 0.60 & 0.99 & 0.99 & 0.99 & 0.99 & 0.60 & 1.17 & 0.81 & 0.81 \\
\hline Downstream length (m) & - & 0.99 & 0.60 & 1.38 & 0.99 & 0.99 & 0.99 & 0.99 & 0.60 & 0.81 & 1.17 & 0.81 \\
\hline Number of fish & 20 & 21 & 22 & 11 & 11 & 20 & 20 & 10 & 20 & 19 & 20 & 15 \\
\hline Number of upstream entries & & 19 & 13 & 5 & 4 & 10 & 3 & 5 & 1 & 6 & 2 & 13 \\
\hline Number of downstream entries & & 64 & 38 & 52 & 50 & 39 & 37 & 68 & 54 & 39 & 101 & 84 \\
\hline Total number of entries & 38 & 83 & 51 & 57 & 54 & 49 & 40 & 73 & 55 & 45 & 103 & 97 \\
\hline Downstream entry rate $(\%)$ & & 77 & 75 & 91 & 93 & 80 & 93 & 93 & 98 & 87 & 98 & 87 \\
\hline Number of downstream entries per fish & & 0.90 & 0.59 & 0.45 & 0.36 & 0.50 & 0.15 & 0.50 & 0.05 & 0.32 & 0.10 & 0.87 \\
\hline Number of upstream entries per fish & & 3.05 & 1.73 & 4.73 & 4.55 & 1.95 & 1.85 & 6.80 & 2.70 & 2.05 & 5.05 & 5.60 \\
\hline Total number of entries per fish & 1.90 & 3.95 & 2.32 & 5.18 & 4.91 & 2.45 & 2.00 & 7.30 & 2.75 & 2.37 & 5.15 & 6.47 \\
\hline
\end{tabular}

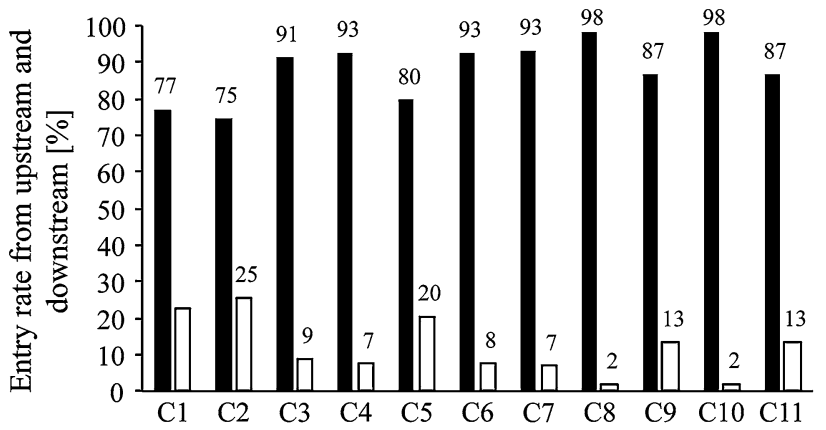

Fig. 12 Entry rate of fish into the refuge near the interface sections that are located downstream (black bars) and upstream (white bars) of the water diverting structure

than for the previously mentioned configurations. The $\mathrm{C} 4$ configuration elicited between three and five entries per fish per test. The greatest movement was observed for the C7 configuration with more than seven entries per fish per test. The fish remained longer in some shelter configurations; however, the fish only used these shelters intermittently for recovery and not as a permanent abode during hydropeaking.
Finally, the video recordings were used to count the number of fish entries in the refuge for each configuration along the interface section that was divided into $0.1-\mathrm{m}$ intervals (see Table 5). These values were combined with the velocities at a $0.025-\mathrm{m}$ depth above the bottom within the same interval to determine the preferred fish velocities, as is shown in Fig. 14 for the $\mathrm{C} 4$ and $\mathrm{C} 8$ configurations. The highest number of entries occurred in the shear layers between the inflowing and outflowing water, where the most frequent velocities ranged between 0 and $0.2 \mathrm{~m} / \mathrm{s}$, reaching values up to $0.3 \mathrm{~m} / \mathrm{s}$. The distribution of the preferred velocities for the entry of the fish into the refuge corresponded to the distribution that has been observed for juvenile brown trout in rivers (Souchon et al. 1989; Vismara et al. 2001; Ayllón et al. 2009).

\section{Discussion}

The fish could easily find a refuge during hydropeaking when a certain amount of water was diverted from the
Fig. 13 Example of video image processing for configuration $\mathrm{C} 4$, showing trajectories of juvenile trout entering the refuge from downstream and their position in the refuge: comparison with the velocity field simulated using 2D BASEMENT

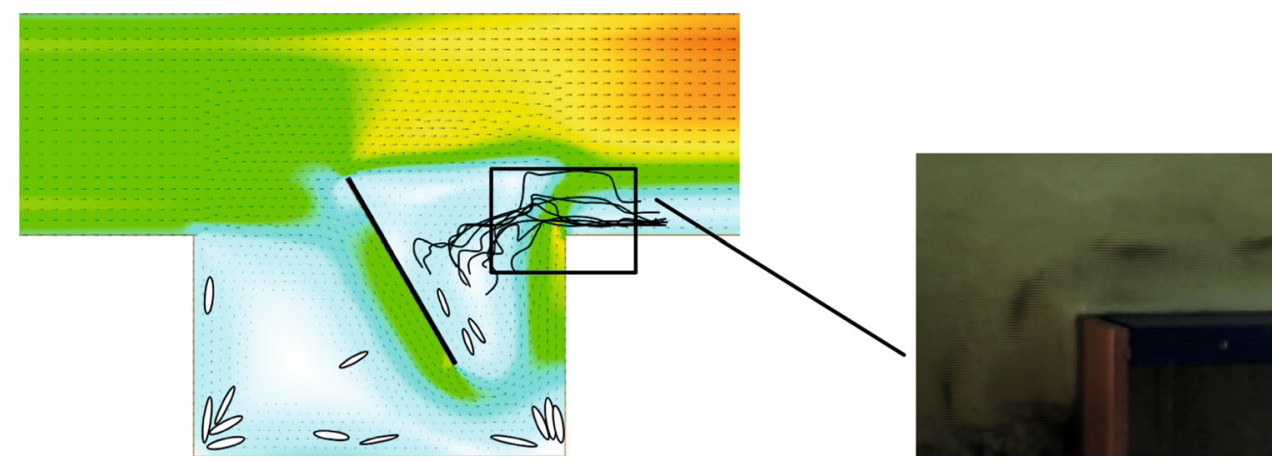


Table 5 Number of fish passages entering the shelter, counted in intervals of $10 \mathrm{~cm}$ along the interface section between the shelter and the channel for each test configuration: the distance is measured from the upstream corner of the shelter; the bold line indicates the position of the diverting structure

\begin{tabular}{|c|c|c|c|c|c|c|c|c|c|c|c|c|}
\hline Configuration & $\mathrm{CO}$ & $\mathrm{C} 1$ & $\mathrm{C} 2$ & $\mathrm{C} 3$ & $\mathrm{C} 4$ & C5 & C6 & $\mathrm{C} 7$ & $\mathrm{C} 8$ & $\mathrm{Cg}$ & $\mathrm{C} 10$ & $\mathrm{C} 11$ \\
\hline \multicolumn{13}{|l|}{ Distance $(\mathrm{m})$} \\
\hline 0.00 & \multicolumn{12}{|c|}{ Upper corner of shelter } \\
\hline 0.05 & 0 & 0 & 0 & 0 & 0 & 0 & 0 & 0 & 0 & 0 & 0 & 0 \\
\hline 0.15 & 2 & 1 & 0 & 3 & 0 & 0 & 2 & 0 & 0 & 2 & 0 & 1 \\
\hline 0.25 & 0 & 3 & 0 & 2 & 1 & 1 & 0 & 0 & 1 & 0 & 0 & 3 \\
\hline 0.35 & 2 & 1 & 1 & 0 & 0 & 2 & 0 & 2 & 0 & 1 & 1 & 4 \\
\hline 0.45 & 2 & 8 & 1 & 0 & 2 & 0 & 0 & 2 & 0 & 1 & 1 & 1 \\
\hline 0.55 & 3 & 3 & 0 & 0 & 0 & 2 & 1 & 1 & 0 & 1 & 0 & 1 \\
\hline 0.65 & 1 & 2 & 1 & 0 & 1 & 2 & 0 & 0 & & 0 & 0 & 3 \\
\hline 0.75 & 1 & 0 & 0 & 1 & 0 & 2 & 0 & 0 & & 1 & 0 & 0 \\
\hline 0.85 & 0 & 0 & 2 & 0 & 0 & 0 & 0 & 0 & & 0 & 0 & \\
\hline 0.95 & 3 & 1 & 2 & 5 & 0 & 1 & 0 & 0 & & 0 & 0 & \\
\hline 1.05 & 5 & 1 & 5 & 2 & 1 & 0 & 0 & 0 & & 0 & 0 & \\
\hline 1.15 & 3 & 0 & 1 & 2 & 1 & 2 & 1 & 0 & & 0 & 0 & \\
\hline 1.25 & 2 & 0 & 0 & 5 & 4 & 4 & 0 & 2 & & 0 & 1 & 5 \\
\hline 1.35 & 0 & 2 & 0 & 7 & 3 & 5 & 3 & 14 & & 0 & 4 & 19 \\
\hline 1.45 & 1 & 5 & 6 & 7 & 2 & 6 & 2 & 17 & 4 & 0 & 8 & 12 \\
\hline 1.55 & 1 & 7 & 9 & 6 & 8 & 3 & 6 & 11 & 18 & 3 & 7 & 10 \\
\hline 1.65 & 2 & 14 & 3 & 10 & 15 & 4 & 7 & 9 & 9 & 6 & 18 & 13 \\
\hline 1.75 & 8 & 16 & 7 & 4 & 11 & 8 & 10 & 6 & 10 & 13 & 20 & 17 \\
\hline 1.85 & 3 & 14 & 10 & 3 & 5 & 6 & 6 & 6 & 13 & 14 & 34 & 8 \\
\hline 1.95 & 1 & 5 & 3 & 0 & 0 & 1 & 2 & 3 & 0 & 3 & 9 & 0 \\
\hline 2.00 & \multicolumn{12}{|c|}{ Lower corner of shelter } \\
\hline
\end{tabular}

channel into the refuge. A simple diverting wall was used for the $\mathrm{C} 1$ configuration, which significantly increased the utilization rate of the shelter to $74 \%$ during hydropeaking in the tests (Fig. 9) for a diverted discharge of $43 \mathrm{l} / \mathrm{s}$ (Fig. 10), which corresponded to $19 \%$ of the channel discharge. No significant trend was observed for the relative attraction of the fish to the tested configurations for discharges that were diverted by more than $15 \%$. However, on average, a utilization rate in the $75 \%$ range was observed for all of the tested water diverting structures (Fig. 11). The fish primarily entered the refuge from downstream for most of the configurations with an entry rate that was above $85 \%$ (Fig. 12). In some configurations (C5 and C2), more than $20 \%$ of the fish also entered from upstream. However, these configurations did not exhibit the best overall utilization rate (Fig. 9). The fish entered from downstream in the most attractive configurations, C3, C8 and $\mathrm{C} 10$, with utilization rates above $80 \%$. As previously mentioned, the highest number of entries occurred in the shear layers between the water flowing into and out of the refuge, where the most frequent velocities $2.5 \mathrm{~cm}$ above the bottom ranged between 0 and $0.2 \mathrm{~m} / \mathrm{s}$, with values up to $0.3 \mathrm{~m} / \mathrm{s}$. However, the large number of fish entries cannot be explained only in terms of such low velocities. The fish appeared to be attracted to low velocities in the shear flow zones where water entered and left the refuge at the same time. This flow structure involving velocity shear zones appeared to be highly significant for creating an attractive refuge. However, the water jet that was issued at the lower edge of the shelter back into the channel, which is shown in Fig. 5 for configuration 8, was also very important in enabling the fish to find the shelter.

An entrance configuration for a refuge should be selected based on the utilization rate as well as the feasibility of the configuration in terms of its structural stability and integration into the river. As previously mentioned, configurations $\mathrm{C} 3, \mathrm{C} 8$ and $\mathrm{C} 10$ had the highest utilization rates $(>80 \%)$. The $\mathrm{C} 3$ and $\mathrm{C} 10$ configurations, in which 
simple walls were used as water diverting structures, are not recommended because these configurations poorly satisfied the feasibility criterion for prototypes. In a prototype refuge, a thin wall would need to be simulated using
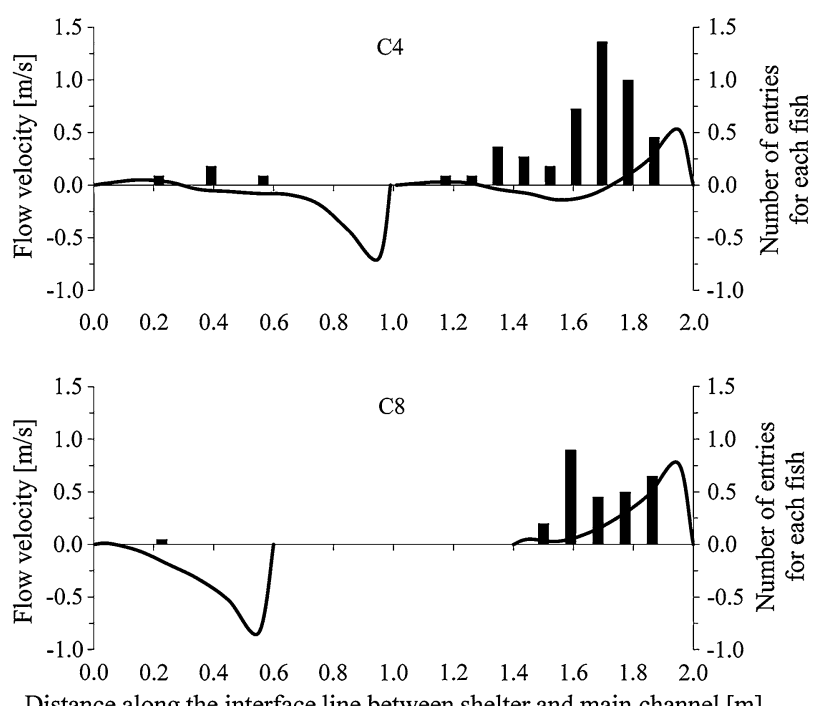

Fig. 14 Distribution of flow velocities along the interface line (solid line) between the channel and the refuge at $0.025 \mathrm{~m}$ above the bottom, superimposed on the distribution of the number of entries per fish (vertical bars) and per 0.1-m interval for configurations $\mathrm{C} 4$ and $\mathrm{C} 8$ a groyne. The required protrusion into the main channel would produce scouring, endangering the stability of the head of the groyne. Thus, the $\mathrm{C} 8$ and $\mathrm{C} 11$ configurations, which are characterized by a deflecting structure such as a triangular island, could be considered to be more favorable in terms of stability and erosion resistance, if properly constructed. C8 should be preferred over C11. C8 exhibited the highest utilization rate (87\%), and the arrangement of the island, which pointed toward the interior of the refuge, occupied less space in the shelter, thereby creating more attractive flow conditions for the habitat of small aquatic organisms. Moreover, the velocity fields obtained using 2D numerical simulations showed that the derived flow followed a more clearly defined path and that the rotation cells were larger for $\mathrm{C} 8$ than in the other configurations. The small number of entries for the $\mathrm{C} 8$ configuration (which exhibited an average of 2.7 entries per fish per test) led us to conclude that this configuration provided more stable conditions that favored the presence of fish in the refuge. In configuration $\mathrm{C} 11$, fish movement into and out of the refuge was characterized by a high average number of entries of 6.5 per fish per test, indicating that the fish were less comfortable in this refuge. Finally, the contraction of the flow in the main channel in front of the island was less marked than for the $\mathrm{C} 8$ configuration. Therefore, the $\mathrm{C} 8$ configuration is recommended as a reference for experimental prototype shelters.
Fig. 15 Sketches of the proposed refuge for entrance configuration $\mathrm{C} 8$, showing the minimum dimensions $[\mathrm{m}]$ : a top view and $\mathbf{b}$ cross-section

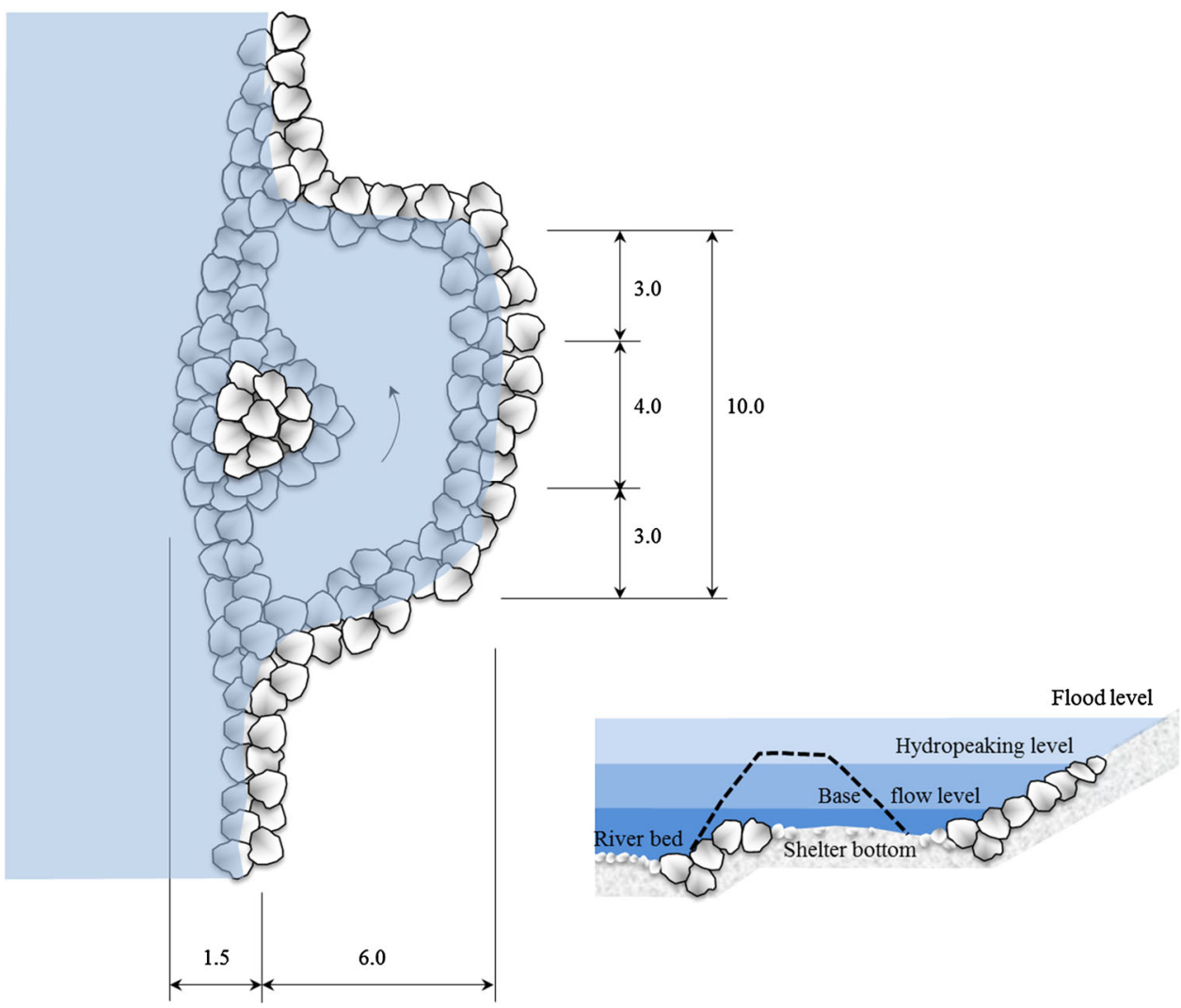


For practical applications, it is important to reproduce the same flow structure and the diverted discharge from the main channel into the refuge as observed in the experiments. The horizontal velocity distribution at the interface between the main channel and the refuge, as illustrated in Fig. 14, was a critical feature of the flow structure. Figure 15 shows that the banks of the refuge and the triangular island were designed to produce a similar diverted flow pattern as that observed in the experiments. Preliminary tests using driftwood in a physical experiment showed that openings of at least $3 \mathrm{~m}$ should be used on both sides of the island to prevent the shelter from being clogged by accumulated driftwood. Thus, the minimum length of a refuge should be on the order of 10-15 m. However, a small accumulation of driftwood and fine sediments in the water recirculation zones of the refuge could even be advantageous for creating additional shelter and habitats for aquatic organisms. To prevent diversion of bedload transport from the main channel into the refuge, the bottom of the refuge should be approximately $1 \mathrm{~m}$ above the riverbed. In addition, during low water conditions, a minimum water depth of at least $0.5 \mathrm{~m}$ should always cover the bottom of the refuge to avoid any stranding of aquatic organisms. The flow velocities through the refuge are sufficiently high to prevent significant deposition of fine suspended sediment, except in the water recirculation and calm water zones, depending on the geometry chosen in practice. As previously mentioned, the local deposition of fine sediments, such as sand and silt, can be considered to be favorable for the habitat potential of the refuge. Riparian vegetation at the refuge banks may also be an important issue in practical applications.

The favorable flow-through conditions that were observed for the $\mathrm{C} 8$ configuration lead us to expect that this configuration can also improve both the entrainment and circulation of food organisms (drifting macro-invertebrates) in the refuge area. A refuge habitat that provides foraging opportunities may be very important for fish growth, especially when hydropeaking events occur frequently or for long periods of time. The refuge could also provide an optimal level of visual cover for juvenile trout combined with using the aforementioned bank vegetation as overhead cover, which would allow greater numbers of these territorial fish to occupy the refuge area.

\section{Conclusions}

Different entrance configurations of fish shelters were installed laterally in a channel for experimental tests on juvenile brown trout. Even under severe hydropeaking conditions, i.e., a sudden increase of 22 times base discharge, juvenile brown trout could rapidly find the shelter as long as the water exchange between shelter and channel was sufficiently high to attract fish. This optimum behavior was obtained when approximately $20 \%$ of the main channel flow was diverted into the lateral shelter. These conditions were obtained by placing a water diverting structure using a wall and island shapes in the middle of the embayment that slightly protruded into the main channel. The ability of the shelter to attract fish was analyzed by testing different orientations and protrusions of the diverting structure. Favorable conditions for attracting fish corresponded to water entering and leaving the shelter at the same time upstream and downstream of the diverting structure. When the fish headed into the shelter, the preferred fish flow path was in the shear zone between the flow entering and leaving the shelter, where the velocities were nearly zero.

Most of the fish found the shelter from downstream by swimming along the bank up to the jet leaving the refuge. After passing this jet, the fish easily entered the shelter along the aforementioned shear zone at very low flow velocities. When coming from upstream, the fish were also guided by the flow that was diverted into the shelter.

Systematic tests showed that a water diverting structure in the shape of a triangular island exhibited strong potential for attracting trout into the shelter. The tested refuge could only be considered to be a mitigation measure for hydropeaking in channelized rivers. On this basis, this research study will be followed up by implementing and monitoring prototype experimental shelters in a channelized river in a hydropeaking regime. Thus, the performance of this solution will be tested continuously in the natural environment using a variety of fish species at different stages of growth. Furthermore, the habitat potential for other aquatic organisms than fish will also be assessed by in situ monitoring.

Acknowledgments This research was conducted as part of the project "Sustainable use of hydropower: Innovative measures for reducing the impacts of hydropeaking", which was financed by the Swiss Innovation Promotion Agency, KTI-CTI contract No. 9676.1. The study was also supported within the framework of the research program "Integrated management of river systems" by the Swiss Federal Office for Environment. The experimental flume was installed and operated with the support of the University of Applied Science Western Switzerland and the electricity power company Groupe-E.

\section{References}

Arrignon J (1998) Aménagement piscicole en eu douce. Editions Technique and Documentation. ISBN2-7430-0241-7

Ayllón D, Almodóvar A, Nicola GG, Elvira B (2009) Interactive effects of cover and hydraulics on brown trout habitat selection patterns. River Res Appl 25:1051-1065

Baumann P, Klaus I (2003) Conséquences écologiques des éclusées, Etude bibliographique, Informations concernant la pêche no 75, Office Fédéral de l'Environnement, OFEV, Berne, Suisse

Bruder A, Vollenweider S, Schweizer S, Tonolla D, Meile T (2012) Schwall und Sunk: Auswirkungen auf die Gewässerökologie 
und mögliche Sanierungsmassnahmen. Wasser-Energie-Luft 104(4):257-264

Bruno MC, Maiolini B, Carolli M, Silveri L (2009) Impact of hydropeaking on hyporheic invertebrates in an Alpine stream (Trentino, Italy). Annales de Limnologie. Int J Limnol 45:157-170

Capra H, Ovidio M, Pella H, Bergé J, McNeil E (2012) Fish response to artificial flow and water temperature variability in a large river (Rhône, France). In: Mader H, Kraml J (eds.) Proceedings of the 9th international symposium on ecohydraulics (ISE 2012). University of Natural Resources and Life Sciences (BOKU) Vienna, ID 17331, p 5

Carolli M, Bruno MC, Siviglia A, Maiolini B (2012) Responses of benthic invertebrates to abrupt changes of temperature in flume simulations. River Res Appl 28(6):678-691

Courret D, Chanseau M, Lascaux J-M, Larinier M (2012) Issue of ecological impacts due to hydropeaking management characterization of hydropeaks - operating experience on Maronne River. La Houille Blanche 67(1):8-14 (in French)

Eberstaller J, Pinka P (2001) Trübung und Schwall AlpenrheinEinfluss auf Substrat, Benthos, Fische, Teilbericht Fischökologie, Abteilung für Hydrobiologie, Fischereiwirtschaft und Aquakultur, Internationale Regierungskommission Alpenrhein Projektgruppe Gewässer- und Fischökologie, Wien

Elliott JM (1994) Quantitative ecology and the brown trout. Oxford University Press, Oxford. ISBN0-19-854678-5

Faeh R, Mueller R, Rousselot P, Vetsch D, Volz C, Vonwiller L, Veprek R, Farshi D (2010) System manuals of BASEMENT, Version 2.1. Laboratory of Hydraulics, Glaciology and Hydrology_VAW. Swiss Federal Institute of Technology Zurich

Fette M, Weber C, Peter A, Wehrli B (2007) Hydropower production and river rehabilitation: a case study on an alpine river. Environ Model Assess 12:257-267

Fischnetz (2004) Network Declining Fish Yields Switzerland. Final report. EAWAG/OFEV

Flodmark LEW, Forseth T, L'Abée-Lund JH, Vøllestad LA (2006) Behaviour and growth of juvenile brown trout exposed to fluctuating flow. Ecol Freshw Fish 15:57-65

Gostner W, Lucarelli C, Theiner D, Kager A, Premstaller G, Schleiss AJ (2011) A holistic approach to reduce negative impacts of hydropeaking. In: Schleiss AJ, Boes RM (eds) Dams and reservoirs under changing challenges. Taylor and Francis Group, London, pp 857-865

Gouraud V, Capra H, Sabaton C, Tissot L, Lim P, Vandewalle F, Fahrner G, Souchon Y (2008) Long-term simulations of the dynamics of trout populations on river reaches bypassed by hydroelectric installations - analysis of the impact of different hydrological scenarios. River Res Appl 24:1185-1205

Greenberg L, Svendsen P, Harby A (1996) Availability of microhabitats and their use by brown trout (Salmo trutta) and grayling (Thymallus thymallus) in the River Vojman, Sweden. Regul Rivers: Res Manag 12:287-303

Heggenes J, Saltveit J, Lingaas O (1996) Predicting fish habitat use to changes in water flow: modelling critical minimum flows for Atlantic salmon, Salmo salar, and brown trout, Salmo trutta. Regul Rivers: Res Manag 12:331-344

Heller P, Schleiss AJ (2011) Aménagements hydroélectriques fluviaux à buts multiples: résolution du marnage artificiel et conséquences sur les objectifs écologique, énergétique et social. La Houille Blanche 66(6):34-41

Jensen AJ, Johnsen BO (1999) The functional relationship between peak spring floods and survival and growth of juvenile Atlantic Salmon (Salmo salar) and Brown Trout (Salmo trutta). Funct Ecol 13:778-785

Jones JI, Murphy JF, Collins AL, Sear DA, Naden PS, Armitage PD (2011) The impact of fine sediment on macro-invertebrates. River Res Appl 27:1055-1071
Jungwirth M, Haidvogel G, Moog O, Muhar S, Schmutz S (2003) Angewandte Fischökologie an Fliessgewässern, UTB Verlag Wien

Korman J, Campana SE (2009) Effects of hydropeaking on nearshore habitat use and growth of age-0 rainbow trout in a large regulated river. Trans Am Fish Soc 138:76-87

Küttel S, Peter A, Wüest A (2002) Rhone Revitalisierung, Temperaturpräferenzen und -limiten von Fischarten. Schweizerischer Fliessgewässer, Publikation Nr. 1

Meile T, Boillat J-L, Schleiss AJ (2011a) Hydropeaking indicators for characterization of the Upper-Rhone River in Switzerland. Aquat Sci 73:171-182

Meile T, Boillat J-L, Schleiss AJ (2011b) Flow resistance caused by large-scale bank roughness in a channel. J Hydraul Eng 137(12):1588-1597

Met-Flow (2002) UVP monitor-Model UVP-DUO User guide. http:// www.met-flow.com

Murchie KJ, Hair KPE, Pullen CE, Redpath TD, Stephens HR, Cooke SJ (2008) Fish response to modified flow regimes in regulated rivers. Research methods, effects and opportunities. River Res Appl 24:197-217

Nagrodski A, Raby GD, Hasler CT, Taylor MK, Cooke SJ (2012) Fish stranding in freshwater systems: sources, consequences, and mitigation. J Environ Manag 103:133-141

Ovidio M, Capra H, Philippart J-C (2008) Regulated discharge produces substantial demographic changes on four typical fish species of a small salmonid stream. Hydrobiologia 609:59-70

Person E, Bieri M, Peter A, Schleiss AJ (2014) Mitigation measures for fish habitat improvement in Alpine rivers affected by hydropower operations. Ecohydrology 7(2):580-599

Peter A, Schager E (2004) Le déclin piscicole est dû à une qualité morphologique insuffisante des cours d'eau. Rapport final du projet Réseau suisse poissons en diminution. EAWAG/OFEV

Ribi J-M (2011) Etude expérimentale de refuges à poissons aménagés dans les berges de rivières soumises aux éclusée. $\mathrm{PhD}$ Thesis No. 5173, Ecole Polytechnique Fédérale de Lausanne, Switzerland and Communication 50 of the Laboratory of Hydraulic Constructions (LCH), Ed. A. Schleiss, Lausanne 2012. ISSN16611179

Ribi J-M, Boillat J-L, Schleiss AJ (2010) Flow exchange between a channel and a rectangular embayment equipped with a diverting structure. In: Dittrich A, Koll K, Aeberle J, Geisenhainer P (eds) Conf. River Flow 2010, 8-10 September 2010, Braunschweig, Germany. Bundesanstalt für Wasserbau, pp 665-671

Schager E, Peter A, Burhardt-Holm P (2007) Status of young-of-year brown trout (Salmo trutta fario) in Swiss streams: factor influencing YOY trout recruitment. Aquat Sci 69:41-50

Schleiss A (2007) L'hydraulique suisse: un grand potentiel de croissance par l'augmentation de la puissance. Bull SEV 02(07):24-29

Schleiss A (2012) Talsperrenerhöhungen in der Schweiz: energiewirtschaftliche Bedeutung und Randbedingungen. WasserEnergie-Luft 104(3):199-203

Scruton DA, Ollerhead LM, Clarke KD, Pennel C, Alfredsen K, Harby A, Kelley D (2003) The behaviour response of juvenile Atlantic Salmon and brown trout to experimental hydropeaking power generation on a Newfoundland river. River Res Appl 19:577-587

Scruton DA, Pennell CJ, Robertson MJ, Ollerhead LMN, Clarke KD, Alfredsen K, Harby A, McKinley RS (2005) Seasonal response of juvenile Atlantic salmon to experimental hydropeaking power generation in Newfoundland, Canada. N Am J Fish Manag 25:964-974

Scruton D, Pennell C, Ollerhead L, Alfredsen K, Stickler M, Harby A, Robertson M, Clarke KD, Ledrew L (2008) A synopsis of 'hydropeaking' studies on the response of juvenile Atlantic 
salmon to experimental flow alteration. Hydrobiologia 609:263-275

SFOE (2013) Stand der Wasserkraftnutzung in der Schweiz am 1. Januar 2012. Swiss Federal Office of Energy

Smokorowski KE, Metcalfe RA, Finucan SD, Jones N, Marty J, Power M, Pyrce RS, Steele R (2011) Ecosystem level assessment of environmentally based flow restriction for maintaining ecosystem integrity: a comparison of a modified peaking versus unaltered river. Ecohydrology 4:791-806

Souchon Y, Trocherie F, Fragnoud E, Lacombe C (1989) Les modèles numériques des microhabitats des poissons: application et nouveaux développements. Revue des sciences de l'eau/J Water Sci 2(4):807-830

Taylor MK, Cooke SJ (2012) Meta-analyses of the effects of river flow on fish movement and activity. Environ Rev 20:211-219

Taylor MK, Cook KV, Hasler CT, Schmidt DC, Cooke SJ (2012) Behaviour and physiology of mountain whitefish (Prosopium williamsoni) relative to short-term changes in river flow. Ecol Freshw Fish 21:609-616

Tuhtan JA, Noack M, Wieprecht S (2012) Estimating stranding risk due to hydropeaking for juvenile European grayling considering river morphology. KSCE J Civil Eng 16(2):197-206

Valentin S (1995) Variabilité artificielle des conditions d'habitat et conséquences sur les peuplements aquatiques: effets écologiques des éclusées hydroélectriques en rivière, Etude de cas et approches expérimentales, thèse, Université Claude BernardLyon

Valentin S (1996) Modeling temporal variations of physical habitat for brown trout (Salmo trutta) in hydropeaking conditions. Regul Rivers: Res Manag 12:317-330

Vismara A, Azzellino R, Bosi R, Crosa G, Gentili G (2001) Habitat suitability curves for brown trout (Salmo trutta fario L.) in the river Adda, northern Italy: comparing univariate and multivariate approaches. Regul Rivers: Res Manag 17:37-50

Wedemeyer GA, Wydoski RS (2008) Physiological response of some economically important freshwater salmonids to catch-andrelease fishing. North Am J Fish Manag 28(5):1587-1596

Young PS, Cech JJ Jr, Thompson LC (2011) Hydropower-related pulsed-flow impacts on stream fishes: a brief review, conceptual model, knowledge gaps, and research needs. Rev Fish Biol Fish 21(4):713-731

Zolezzi G, Siviglia A, Toffolon M, Maiolini B (2011) Thermopeaking in Alpine streams: event characterization and times scales. Ecohydrology 4(4):564-576 